\title{
MANAGING CORPORATE WAQF IN MALAYSIA: PERSPECTIVES OF SELECTED SEDCs AND SIRCs
}

\author{
Norma Md Saad ${ }^{1}$ \\ Suhaimi Mhd Sarif ${ }^{2}$ \\ Ahmad Zamri Osman ${ }^{3}$ \\ Zarinah Hamid ${ }^{4}$ \\ Muhammad Yusuf Saleem ${ }^{5}$
}

\begin{abstract}
Waqf is described as an act of dedicating a corpus of property or financial assets in perpetuity for the cause of Allah SWT. The ownership of the property or assets is transferred to Allah SWT, but the benefits are dedicated to the poor, sick, marginalized segments of society, or any other virtuous causes. Waqf institutions are among several instruments instituted in Islam to combat poverty and enhance societal welfare. Waqf provides
\end{abstract}

\footnotetext{
Professor, Kulliyyah of Economics and Management Sciences, International Islamic University, 53100 Kuala Lumpur, norma@iium.edu.my

2 Associate Professor, Kulliyyah of Economics and Management Sciences, International Islamic University, 53100 Kuala Lumpur, suhaimims@iium.edu.my

3 Assistant Professor, Kulliyyah of Economics and Management Sciences, International Islamic University, 53100 Kuala Lumpur, azamrio@iium.edu.my

4 Professor, Kulliyyah of Economics and Management Sciences, International Islamic University, 53100 Kuala Lumpur, inahumkc@iium.edu.my

5 Associate Professor, International Centre for Education in Islamic Finance, Lorong Universiti A, Universiti Malaya, 59100 Kuala Lumpur, yusuf@inceif.org
} 
the material infrastructure and creates a source of revenue for use in, among other things, social welfare enhancing activities, both at the family, community, and state levels. Corporate waqf is defined as a type of waqf where the mawqüf (waqf assets) are in the form of shares issued and managed by a corporate entity. Corporate waqf utilizes the application of waqf principles in a corporate setting. ${ }^{6}$ Corporate waqf is more than a charitable and philanthropic act by a business entity, but is an initiative to combine the concept of waqf and apply it to achieve business and corporate objectives. Consequently, it intends to redefine the role and function of business organizations in today's society by 'giving back' and reaching out to the community. This study tries to gauge the level of awareness and willingness of State Economic Development Corporations (SEDCs) and State Islamic Religious Councils (SIRCs) to be involved in corporate waqf initiatives. The study found that, in general, the SEDCs are receptive of the idea of corporate waqf entities managing and enhancing the values of waqf assets and waqf properties; however, this must be done within the current legal framework. The study also found a lack of coordination between the SEDCs and SIRCs in making decisions on waqf related matters. It is suggested that the state government, through its departments/agencies, play a facilitative role in ensuring the efficient development of waqf assets or properties.

Keywords: waqf, corporate waqf, waqf management, Baitul Mal, Malaysia

\section{INTRODUCTION}

The word waqf literally means to 'stop, prevent, detain or to keep in custody'. In legal terms, waqf is defined as a perpetual dedication of a certain property to Allah SWT by devoting its benefit to religious and charitable causes. ${ }^{7}$ In otherwords, The ownership of the property or assets are transferred to Allah SWT but the benefits are dedicated to the poor, sick, marginalized, or any other virtuous causes. The main purpose of sacrificing these properties or assets is to gain the pleasure of Allah of SWT. On the other hand, corporate waqf is defined as a type of waqf where the mawqüf (waqf assets) are in the form of

6 Investment and Finance, 'Corporate Waqf,' www.Islamic-finance/c/corporatewaqf.html., accessed on 19 October 2015.

7 See as Sayyid Sābiq, Fiqh al-Sunnah (Miṣr: al-Fatḥ li al-I'lām al-'Arabī, 1425/2014), 169. 
Managing Corporate Waqf in Malaysia: Perspectives of Selected SEDCs and SIRCs

shares issued and managed by a corporate entity. Corporate waqf utilizes the application of waqf principles in a corporate setting. ${ }^{8}$

Waqf institutions have played an important role in Islamic society and in the history of Islamic civilization. This Islamic institution was well spread and accepted as one of the foundations towards build human society especially in providing the basic need and functions as system supporter as well as free infrastructure. The history of Islamic $a w q \bar{a} f$ goes back to the time of the Prophet (peace be upon him). The institution has always provided public goods ranging from education and health care to water supply and highway facilities - all on a voluntary basis by the non-profit sector. However, it has generally been considered as a religious and charitable provision; emphasis on its socioeconomic role is a recent phenomenon.

The institutions of waqf are among several instruments instituted by Islam to combat poverty and enhance the welfare of society. Waqf provides material infrastructure and creates a source of revenue for use in, among others, social welfare enhancing activities at the domestic and state levels. Waqf is a voluntary act of charity that comes under the general terms of șadaqah and infāq.

Muslims are inspired to spend on charity as emphasized by many verses of the Holy Quran and the narrations of Prophet Muhammad SAW. For instance, the Holy Quran states:

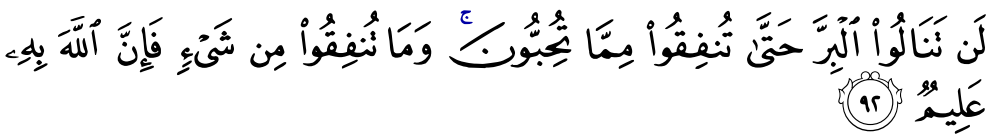

"Even so, O believers, you shall never attain to the highest virtue of faith until you spend in charity from that which you love. And anything you spend, indeed, God is all-knowing of it."

(Surah Āli‘Imrān, 3: 92)

The encouragement of performing an act of waqf during the Prophet's (peace be upon him) time is recorded in Șaḥih Muslim:

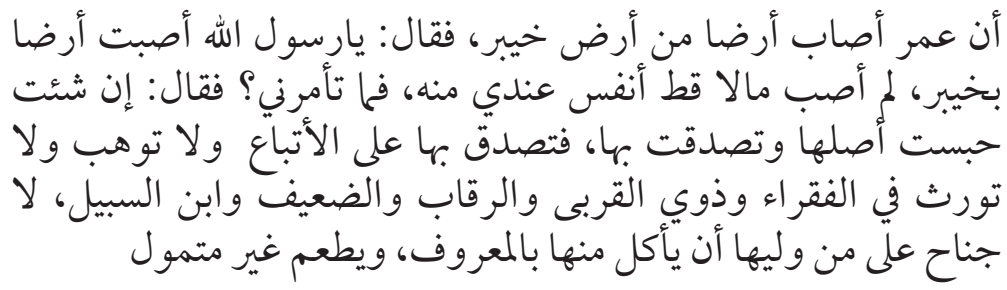

8 Investment and Finance, 'Corporate Waqf,' www.Islamic-finance/c/corporatewaqf.html., accessed on 19 October 2015. 
"Ibn 'Umar reported: 'Umar acquired a land at Khaybar. He came to Allah's Apostle (peace be upon him) and sought his advice in regard to it. He said: Allah's Messenger, I have acquired land in Khaybar. I have never acquired property more valuable for me than this, so what do you command me to do with it? Thereupon he (Allah's Apostle) said: If you like, you may keep the corpus intact and give its produce as șadaqah. So 'Umar gave it as sadaqah declaring that property must not be sold or inherited or given away as gift. And 'Umar devoted it to the poor, to the nearest kin, and to the emancipation of slaves, aired in the way of Allah and guests. There is no sin for one, who administers it if he eats something from it in a reasonable manner, or if he feeds his friends and does not hoard up goods (for himself)." 9

The practice of waqf in Malaysia can be traced back to the Malacca Sultanate in the 15 th century. ${ }^{10}$ During this period, waqf was one of the popular practices among Muslims in the Malay Peninsula. The development of waqf properties went through significant changes during the colonization period by the Portuguese (1511-1641), the Dutch (1641-1824), and the British (18261946). Gradually, the responsibility of waqf management was placed under the respective State Islamic Religious Councils (SIRCs). On 27 March 2004, the government of Malaysia set up Jabatan Wakaf, Zakat dan Haji (Department of Wakaf, Zakat and Hajj, JAWHAR) to monitor the effectiveness and efficiency of waqf, zakāh, and hajj administration in every state in Malaysia. ${ }^{11}$

Although, historically, waqf has been proven to be an effective tool in eliminating hunger and poverty, while promoting equitable wealth distribution, studies have shown that contemporary waqf institutions are facing several management issues which has led to abandonment and underdevelopment of waqf assets. However, some researchers ${ }^{12}$ have proposed the use of corporate management systems and strategies that could lead to efficient and effective resource mobilization.

9 Muslim Ibn al-Hajjāj Abū al-Ḥasan al-Qushayrī al-Naysābūrī, Șaḥịh Muslim,Sahih, Book 13, The Book of Bequests (Kitab al-Wasiyyah), Hadìth no. 4006, https:// d1.islamhouse.com/data/en/ih_books/single/en_Sahih_Muslim.pdf

10 Aun. W. M., An Introduction to the Malaysian Legal System (Kuala Lumpur: Heinemann Educational Book, Asia Limited, 1975).

11 JAWHAR, 'Sejarah JAWHAR,' 2012, http://www.jawhar.gov.my/profil-jabatan/ mengenai-jawhar/sejarah-jawhar/

12 Megat Abdul Rahman, M. M. G. \& Othman, A., 'Development of Waqf Land: Issues, Prospect, and Strategies,' Malaysian Journal of Real Estate, 2 (2006): 3946. 
Managing Corporate Waqf in Malaysia: Perspectives of Selected SEDCs and SIRCs

The primary objective of this study is to gauge the level of awareness and willingness of the State Economic Development Corporations (SEDCs) and State Islamic Religious Councils (SIRCs) to be involved in corporate waqf initiatives. In addition, this study seeks to explore new ways of managing and investing in waqf assets while identifying the best management practices for the adoption by corporate waqf institutions. Furthermore, this study hopes to provide policy recommendations to waqf authorities and other relevant government agencies on ways to enhance the efficiency of the waqf institutions.

\section{LITERATURE REVIEW ON CORPORATE WAQF}

In Malaysia, corporate waqf is a relatively new idea introduced by the state economic development corporation of Johor; Johor Corporation in 2006. It is an idea combining corporate efforts with the aim of giving back to society through the awqāf concept. Corporate waqf is a recent innovation with the intention to revitalize the once powerful waqf institution and benefit from its dynamism towards adding value and producing wealth through business and corporate efforts to encourage economic growth.

Corporate waqf, according to the Waqaf An-Nur Corporation (2008), is more than a charitable and philanthropic act by a business entity; it is an initiative to combine the waqf concept and apply it to achieve business and corporate objectives. Corporate waqf, consequently, intends to redefine the role and function of business organizations by 'giving back' to society and reaching out to the community.

One great advantage of corporate waqf is its longevity. It is important to address the issue of maintaining corporate ownership and continuity in an effort of servicing the Muslim ummah. When it is appropriately structured, properly planned and organized, and efficiently managed, corporate waqf can be anticipated to have all the competence, potential, and vitality of any wellfunctioning corporate entity.

The initiative taken by Johor Corporation to launch Waqaf An-Nur Corporation Berhad (WANCorp) as a corporate waqf entity is for the sake of providing a model for other Malaysian - and other global private companies - to actively promote, establish, and develop waqf assets. However, the development of corporate waqf in Malaysia has not progressed as well as predicted. Hanefah et al. express that government involvement is important 
in enhancing and stimulating philanthropic institutions to achieve their main target of improving the socio-economic welfare of society. ${ }^{13}$

The issues of waqf centre on two main areas: managerial and legislative. According to Kahf, the waqf management system initially faced an array of problems and attempts were made in some Muslim countries to reform waqf management. ${ }^{14}$ Chowdhury et al. identified three main problems facing waqf management in Malaysia. The first problem arises when the State Islamic Religious Council (MAIN) employ professionals who are unqualified and who do not know their job functions and responsibilities in managing waqf institutions; sometimes these professionals are not familiar with Islamic law and the laws of the country. Secondly, there are instances whereby the mutawalli (trustee of waqf properties) appoint non-Muslims to manage waqf lands, hence their level of commitment and ability to run waqf assets with trust and reliance are questionable. Another problem related to waqf management in Malaysia are abandoned and undeveloped waqf properties. The issue of properties being left idle is not new and the factors that inhibit the development of waqf properties are also publicly known. ${ }^{15}$ According to Megat Abdul Rahman and Othman (2006), the limited provisions to develop waqf properties and a weak administrative system have hindered these institutions from generating income that could benefit society. To overcome these problems, they proposed several recommendations such as, designing innovative waqf management systems and strategies that could lead to efficiency and which could mobilize resources effectively. ${ }^{16}$

\section{METHODOLOGY}

The study uses primary data to gauge the level of awareness of the top management of State Economic Development Corporations (SEDCs) and

13 Hanefah et al., 'Waqf Models in Iskandar Malaysia: An Analysis,' https://comaif. files.wordpress.com/2013/09/2010-usim-waqf-models-in-iskandar-malaysia-fullpaper.pdf., accessed on 20 October 2015.

14 Kahf, M., 'The Role of Waqf in Improving the Ummah Welfare,' (Paper presented in the International Seminar on Waqf as a Private Legal Body, Medan, 6-7 January 2004).

15 Chowdury, M. S. R. et. al., 'Economics of Cash Waqf Management in Malaysia: A Proposed Cash Waqf Model for Practitioners and Future Researchers,' African Journal of Business Management, 5 (2011): 30.

16 Megat Abdul Rahman, M. M. G. \& Othman, A., 'Development of Waqf Land: Issues, Prospect, and Strategies,' 39-46. 
Managing Corporate Waqf in Malaysia: Perspectives of Selected SEDCs and SIRCs

State Islamic Religious Councils (SIRCs) on the issue of corporate waqf. A written questionnaire was designed as an instrument to obtain information from various SEDCs and SIRCs. The researchers had written to the management of almost all the SEDCs in Malaysia; however, only the SEDCs from the states of Perlis, Kedah, and Perak had responded and agreed to be interviewed. In addition to interviewing the top management of the SEDCs, researchers had also contacted selected SIRCS to obtain information on their views regarding corporate waqf. The SIRCs which have participated in this study are from the states of Negeri Sembilan, Kelantan, and Pahang.

\section{RESULTS AND DISCUSSION}

This section presents the results of interviews conducted with the management sectors of SEDCs in Perak, Kedah, and Perlis, followed by SIRCs of Pahang, Kelantan, and Negeri Sembilan. The interviews with SEDCs were conducted between July-September 2014, whereas those with SIRCs were carried out between March-June 2015.

\section{State Economic Development Corporations (SEDCs)}

The feedback given by the managers of SEDCs in Perak, Kedah, and Perlis are analysed according to four different themes used to develop the questionnaire:

\section{a) Awareness of Corporate Waqf Initiatives}

The purpose of this section was to gauge the managers' level of awareness of different aspects of corporate waqf initiatives in their respective states. When asked whether they were aware of the modernized version of waqf activities the managers from Perak and Kedah replied in the affirmative whereas the managers of SEDCs from Perlis were neutral. In addition, all the managers agreed on the need to empower the proposed waqf entity to make decision with regard to the management of corporate entities that have been converted to waqf, and it should be allowed to tackle the ensuing financial difficulties.

There were mixed responses to the question as to whether the SEDC was aware that some corporate entities and institutions were registered as waqf entities. The managers from Perak and Perlis agreed that the SEDC was aware that any established waqf institutions (whether traditionally managed through state owned entities or state-linked companies) would be able to offer value to waqf beneficiaries, but Kedah disagreed in this regard. The majority of 
managers also agreed that waqf institutions managed with corporate entities could yield better value to waqf properties due to management through a collective and objective philosophy of the corporate entities.

However, there was unanimous agreement on the observation that even though the waqf institutions were based on Islamic law, they could still be managed efficiently and effectively by corporate entities. Managers realized that the management of corporate waqf institutions would face external as well as internal challenges, but would be able to overcome the challenges by objective orientation. They were positive that the management of corporate waqf institutions would apply corporate governance to safeguard the interest of the waqf trustees and stakeholders. Table 1 summarizes the feedback of the respondents from Perak, Perlis and Kedah.

Table 1: Summary of Findings on the Awareness of Corporate Waqf Initiatives

\begin{tabular}{llccc}
\hline & \multicolumn{1}{c}{ A. Aware Corporate $\boldsymbol{W a q f}$ Initiatives } & Perak & Perlis & Kedah \\
\hline A1 & Aware of modernized version & 4 & 3 & 4 \\
A2 & Need to empower corp waqf & 4 & 4 & 4 \\
A3 & Aware of financial difficulties & 4 & 4 & 4 \\
A4 & Aware registered as waqf entities & 3 & 4 & 2 \\
A5 & Any form entities offer value waqf beneficiaries & 4 & 4 & 2 \\
A6 & Corporate entities could yield & 4 & 4 & 3 \\
A7 & Comply Islamic law still efficient and effective & 4 & 4 & 4 \\
A8 & Management by objective orientation & 4 & 4 & 4 \\
A9 & Corporate governance to safeguard & 4 & 4 & 4 \\
\hline
\end{tabular}

Note $\quad: 5$ strongly agree 4 agree 3 neutral 2 disagree 1 strong disagree.

Source : Survey, 2014.

In short, there is awareness of the corporate waqf initiatives, but some SEDCs have reservations on the need to register corporate waqf entities and to form entities to increase value to waqf beneficiaries. The main reason is the existing legal framework and the authority of HRH State Rulers. In the case of Kedah, the responses to items A4 and A5 are quite low compared to other states; perhaps due to the administrative structure of Kedah civil service which does not adequately facilitate the corporate waqf initiatives. 
Managing Corporate Waqf in Malaysia: Perspectives of Selected SEDCs and SIRCs

\section{b) The Use of Corporate Entities in Managing Waqf Properties}

In Section B of the questionnaire the respondents were asked to indicate their views on the use of corporate entities to manage waqf properties. There was generally not much disagreement on most of the issues. To begin with, all of them preferred the proposed corporate entities for management of waqf assets/ properties and the majority agreed that corporate business models can be used to enhance the value of waqf properties. There was no dissenting voice against the introduction of a franchising mechanism to manage and enhance the value of waqf assets/properties. There was also general agreement on the possible strategy of mergers or acquisitions with other corporate entities to manage and enhance the value of waqf assets/properties. The managers also felt that corporate waqf entities should intensify efforts to increase participation of waqf assets/properties by marketing activities and developing more waqfbased products from said assets/properties - they could also form a consortium with a few companies to increase the value of waqf properties.

The managers were neutral on the issue of entering into licensing agreements with different companies to increase the value of/or outsource the management of waqf properties.

Finally, there was a mixed response on the subject of flexibility in allowing various departments to get involved in decision making with regard to waqf properties. Table 2 summarizes all the feedback on the use of corporate entity to manage waqf properties.

Table 2: Summary of Feedback on the Use of Corporate Entity to Manage Waqf Properties

\begin{tabular}{llccc}
\hline & $\begin{array}{c}\text { B. Use of Corporate Entity to Manage Waqf } \\
\text { Properties }\end{array}$ & Perak & Perlis & Kedah \\
\hline B1 & Managing waqf assets/properties & 4 & 4 & 4 \\
B2 & Enhancing the value of waqf properties & 4 & 3 & 4 \\
B3 & Franchising mechanism enhance value & 3 & 4 & 4 \\
B4 & Merger or acquisition approach & 4 & 4 & 4 \\
B5 & Enhance participation of waqf assets/properties & 4 & 4 & 4 \\
B6 & Develop waqf-based products & 4 & 3 & 4 \\
B7 & Could form a consortium & 4 & 4 & 4 \\
B8 & Could form licensing agreements with companies & 3 & 3 & 3 \\
B9 & Could outsource the management of waqf properties & 4 & 3 & 3 \\
B10 & Apply flexible management & 2 & 3 & 3 \\
\hline
\end{tabular}

Source: Survey, 2014. 
In short, the respondents are agreeable to using corporate entities to manage waqf properties, but have reservations regarding using business mechanisms such as franchising, licensing, and flexible management, as these practices might contradict the existing legal framework and the authority of HRH State Rulers.

\section{c) Resources Required for Proposed Corporate Entities to Manage Waqf Properties}

When asked to indicate their views on the requirement of resources for proposed corporate entities to manage waqf properties, all of the respondents agreed that they would receive adequate resources to manage and maintain the waqf properties, and the monthly expenses for the proposed waqf unit would be incorporated into the existing remuneration system. They were generally neutral about the human resources strength of the unit and allocation of the monthly expenses for maintaining properties. Also, there were highly varied responses on areas such as empowerment of management and the need for proper training.

Table 3 summarizes the feedback of the respondents on part $\mathrm{C}$ of the questionnaire that asked for views on the resources required for the proposed corporate entity to manage waqf properties.

In short, respondents had mixed views pertaining to the resources required for proposed corporate entities to manage waqf properties. However, the overall feedback can be considered positive. Some disagreement was noted when they were asked about the empowerment, training, and resources required especially for items 5 and 6 .

Table 3: Resources Required for the Proposed Corporate Entity to Manage Waqf Properties.

\begin{tabular}{|c|c|c|c|c|}
\hline & $\begin{array}{l}\text { C. Resources Required by the Proposed Corporate Waqf } \\
\text { Entity }\end{array}$ & Perak & Perlis & Kedah \\
\hline $\mathrm{C} 1$ & Need minimum resources & 4 & 4 & 4 \\
\hline $\mathrm{C} 2$ & Monthly expenses under existing remuneration package & 4 & 4 & 4 \\
\hline $\mathrm{C} 3$ & Minimum permanent staff from SEDC & 3 & 3 & 3 \\
\hline $\mathrm{C} 4$ & Maintenance expenses part of SEDC allocation & 3 & 4 & 3 \\
\hline $\mathrm{C} 5$ & Corporate waqf enjoys empowerment & 2 & 3 & 4 \\
\hline \multirow[t]{2}{*}{ C6 } & Given adequate and proper training & 2 & 3 & 4 \\
\hline & C. resources required by the proposed corporate waqf entity & & & \\
\hline
\end{tabular}

Source: Survey, 2014. 
Managing Corporate Waqf in Malaysia: Perspectives of Selected SEDCs and SIRCs

\section{d) Financing Waqf Properties}

The financing of corporate waqf entities is an important concern and the survey shows that the proposed management of corporate entities are aware of financial difficulties in managing and maintaining the waqf properties whose expenses are increasing day by day. The majority also agreed that the waqf institutions are given adequate allocation and resources to manage and maintain waqf properties, but they observe that the management is facing financial difficulties and continuously intensifying its efforts to find ways to finance the development of the waqf assets and engaging in discussion with related parties to get the required help.

Furthermore, they feel that currently, the available funds to manage and develop waqf assets are not enough as the expenses to maintain waqf properties are increasing day by day as it is getting more challenging. In other words, matters relating to exorbitant expenses and financial predicaments are acknowledged as serious matters that need dire attention. The respondents feel that investing the waqf assets would help to raise the much needed funding in developing waqf properties and the proposed waqf corporate entities could be given the liberty to find ways to finance the development of said assets. However, currently, not enough funds are available to manage and develop the waqf assets by the proposed waqf institution. However, possible ways exist to finance the development of waqf assets/properties coupled with possible challenges in financing this development.

While commenting on the possible ways to finance the development of waqf assets/properties, a respondent observed that the corporate waqf entities should try to seek funding from Muslim investors in the waqf land development sector. On possible challenges in financing the development of waqf assets, they cited lack of awareness of Muslims about the creation of waqf on their property. A respondent argued that while there is an eagerness to develop waqf land, one has to look at the benefit that could be gained by the surrounding Muslim community and not neglect the rulings of Islam and the relevant laws. Corporate entities need to be established to manage waqf property so that the existing department or unit can focus on their core duties. Table 4 summarizes the feedback from the respondents pertaining to the relevant issues of financing waqf properties. 
Table 4: Issues of Financing Waqf Properties

\begin{tabular}{|c|c|c|c|c|}
\hline & D. Financing Corporate Waqf Entity & Perak & Perlis & Kedah \\
\hline D1 & Aware of financial difficulties & 4 & 5 & 4 \\
\hline D2 & Additional expenses for SEDC & 4 & 5 & 4 \\
\hline D3 & Allocate some resources for maintenance & 4 & 3 & 4 \\
\hline D4 & $\begin{array}{l}\text { Management could face financial and } \\
\text { management challenges }\end{array}$ & 3 & 4 & 4 \\
\hline D5 & Management find alternative ways of financing & 4 & 4 & 4 \\
\hline D6 & $\begin{array}{l}\text { Engage with stakeholders for alternative ways } \\
\text { of financing }\end{array}$ & 4 & 3 & 4 \\
\hline D7 & Existing fund is not enough & 4 & 4 & 4 \\
\hline D8 & Expenses increasing & 3 & 5 & 4 \\
\hline D9 & Financially difficult to manage waqf assets & 4 & 5 & 4 \\
\hline D10 & Invest waqf assets & 4 & 5 & 4 \\
\hline D11 & $\begin{array}{l}\text { Freedom to find ways of financing to develop } \\
\text { waqf assets }\end{array}$ & 4 & 4 & 4 \\
\hline D12 & Not enough fund to develop waqf assets & 4 & 4 & 4 \\
\hline D13 & Confident other ways to get funding & 3 & 4 & 4 \\
\hline D14 & Aware of possible challenges & 3 & 4 & 4 \\
\hline D15 & Possible to develop other means and ways & 3 & 4 & 4 \\
\hline
\end{tabular}

Source: Survey, 2014.

The findings from the survey with respondents from Perak, Kedah and Perlis can be summarized into four points. Firstly, there is awareness of the corporate waqf initiatives, but some SEDCs have reservations on the need to register corporate waqf entities and to form any entities to increase benefits to waqf beneficiaries. The main reason is the existing legal framework and the authority of HRH State Rulers. Secondly, the respondents agree to the use of corporate entities to manage waqf properties, but have reservations on using business mechanisms such as franchising, licensing, and flexible management. They are also afraid of contradicting the existing legal framework and the authority of HRH State Rulers. Thirdly, the respondents have mixed views pertaining to the resources required for the proposed corporate entities to manage waqf properties. Finally, they indicated that SEDC is aware of the financing need for the corporate waqf entities to manage and increase value of 
Managing Corporate Waqf in Malaysia: Perspectives of Selected SEDCs and SIRCs

waqf assets/properties. However, they have some reservations on challenges expected and also to search for ways to finance corporate waqf entities.

Based on the findings, the study suggests the corporate waqf initiatives of SEDCs to use a matrix structure or hybrid organizational mechanism to run the corporate waqf entities with autonomy and a code of governance. While autonomy provides flexibility for managers to decide on corporate decisions and management approaches, the managers should act as agents to their principals. To minimize agency problems an effective corporate governance mechanism is needed.

\section{State Islamic Religious Councils (SIRCs)}

One of the SIRCs which participated in this study is from Negeri Sembilan or Majlis Agama Islam Negeri Sembilan (MAINS). On 10 June 2005, it founded a subsidiary known as Perbadanan Waqaf Negeri Sembilan (PWNS). The establishment of the corporate waqf of Negeri Sembilan is dedicated solely to advancing the mission of MAINS by managing waqf initiatives systematically and professionally. It is $100 \%$ owned by MAINS Holdings Sdn. Bhd. And is currently operating at Taman Komersil Senawang, Negeri Sembilan. ${ }^{17}$ Among the main objectives of its establishment are as follows:

a) To accustom the Muslims in Negeri Sembilan on the functions of waqf

b) To provide business opportunities for those who meet the criteria

c) To promote a systematic and productive waqf management

d) To increase asset holding for the sake of religion and human development in Negeri Sembilan.

e) To generate the socio-economic development of Muslims through the application and utilization of existing sources.

As for the SIRC of Kelantan (SIRCK), the management structure is divided into four broad divisions; the Baitul Mal, Religion/Mosque Administration, Management Services, and Development. Waqf-related matters are managed by a unit under the Development Division. The unit is relatively new as it was established mid-2012. Before its establishment, waqf matters were handled by the Baitul Mal Division. Currently, the unit is staffed with eight people comprising one officer, three assistant officers, and four clerks. In term of qualifications, the officer holds a degree and Postgraduate Diploma in Shari'ah. Meanwhile the qualifications for the assistant officers are diploma

17 Perbadanan Waqaf Negeri Sembilan, Brosur Profil (Negeri Sembilan: PWNS, 2015). 
levels in Land Administration, quantity surveying, and management studies respectively. Meanwhile, for the clerks, one of them holds a degree, another two hold diplomas, and another has a certificate. At the higher level there is a waqf management committee which was recently established (i.e., having its first meeting in May 2015); it comprises 11 members from State departments and agencies such as from the Mufti Office, state legal advisers, Jabatan Kerja Raya (Public Works Department, JKR), including representative from each division within the SRC.

Meanwhile, the SIRC of Pahang (SIRCP) is divided into two broad divisions: Baitul Mal and Management Services. There are five departments in the Baitul Mal Division and four departments in Management Services. Waqf is one of the departments in Baitul Mal, the others being Zakat, Investment, Asnaf Development, and District Administration. There are 13 staff in Waqf Department comprising two officers (degree level), four assistant officers (diploma level), and another seven staff at the clerical level and drivers. The SIRCP also established a Waqf Management committee comprising representative from state departments and agencies.

\section{a) Relationship with State Government}

The Federal Constitution of Malaysia has stated that religious matters including waqf fall under state jurisdiction. This gives the impression that the state has the responsibility and authority in managing waqf assets. However, upon closer observation, the responsibility and authority actually rests on the SIRC rather than the state government. These are two different entities. While the state government is headed by the Chief Minister as the state executive body, the SIRC is headed by the Sultan of the state with varying levels of involvement from the state executive body (depending on the organizational structure of each SIRC). In SIRCK, there are 15 board members chaired by the Regent of the state as the Yang DiPertua ${ }^{18}$ (YDP). Only one of them is from the state executive body (a state exco member). The daily management (equivalent to a CEO) is headed by the Deputy YDP. Meanwhile, in the waqf management committee, there seems to be no member from the executive body - although there are members representing state departments such as JKR and state legal advisers. A similar scenario can be seen in the SIRCP; the board is headed by the regent and the daily management is by the Deputy YDP. Unlike the SIRCK, the state executive body in SIRCP is represented by the Chief Minister himself.

\footnotetext{
18 Equivalent to Chairman.
} 
Managing Corporate Waqf in Malaysia: Perspectives of Selected SEDCs and SIRCs

Based on the interviews conducted with the SIRCs of Kelantan and Pahang, both do not have a formal or direct relationship with the state government. There is no special arrangement with the state government with regard to waqf matters. In SIRCK, the waqf officer highlighted the difficulty in transferring the land title from the donor/waqif's name to the SIRCK. There is a legal provision in the state law regarding ownership of land. The ownership of land in Kelantan can only be afforded to people born in the state of Kelantan. The process is highly bureaucratic. She noted that:

"We do not receive special treatment from the state department. Sometimes, the process may take up to one year...just to get a declaration that the property can be transferred" 19

She noted that the process should be facilitated by the relevant state department since the purpose of transferring the title is for public benefit - the process should not be constrained by legal provision. In addition, the relationship with the state government also involves a staff quota. In several cases, the SIRCK receives officers recruited by the state government to work within the organization. She raised the concern that normally these officers are placed in SIRCK for a relatively short period of time. While the state government assistance in terms of staff provision is commendable, the length of their attachment to SIRCK can disrupt the smooth operation of waqf. She stated that:

"These administrative officer keeps on changing...[making it] difficult..." 20

Meanwhile, in the SIRCP, the waqf officer expressed a similar sentiment. He noted that the SIRCP does not get satisfactory cooperation from the state department or its agencies. Despite being a state level entity, the SIRCP is treated similarly to other parties. One waqf officer noted that:

"We have to climb their office's stairs several times just to attend to one case" 21

This indicates that despite the purpose of making waqf for public benefit (not personal nor for profit), no state government assistance is extended. It appears that not only have state department/agencies not facilitated the waqf, the officer felt that these departments complicate matters when it comes to

\footnotetext{
19 WO, SIRCK.

20 WO, SIRCK.

21 WO2, SIRCP.
} 
waqf issues, as stated by another waqf officer, the state is hindering, and not facilitating on waqf matters.

Both SIRCs may face different levels of assistance from state departments/ agencies. However, what seems to be glaring is that on some occasions these state departments are seen as obstacles in developing and managing waqf properties.

\section{b) Authority to Make Decisions}

The need to have freedom in decision making is paramount in order for a waqf property to enjoy satisfactory establishment and development. This, to a certain extent, is related to the issue of relationships with state governments. The authority in decision making in waqf-related issues may however depend on three inter-related factors (i.e., what are the waqf-related tasks, where waqf is placed in the organizational structure, and the attention given to waqf issues by higher authorities).

Most important issues affecting policy may not be decided by the waqf unit alone; it has to undergo a higher authority of approval of which several other units/departments may have a say. Osman argued that waqf officers may not be able to fully satisfy their responsibility as their job scope may be limited to a certain extent. ${ }^{22}$ In order to see the full potential of waqf properties, waqf matters cannot be restricted to the registration of waqf asset only (i.e., receiving applications and verifying the existence of assets).

The task of receiving applications is relatively easy. However, the ensuing task of verifying and developing them may be more challenging. As indicated previously in the case of staff sharing, even the task of verifying assets can be problematic. In short, while the easier task of attending to applications for waqf is within the waqf unit's capacity, the relatively more important tasks such as verifying and developing are not within their scope. As the ones who are observing and monitoring the waqf asset (and sometimes the waqf beneficiaries), the staff may feel helpless in making necessary changes and development as the authority to allow development is out of their hand. This is indicated in responses by the waqf officers:

22 Osman, A.-Z., 'Accountability in Managing Waqf Properties: The Case of Two State Religious Councils in Malaysia,' (Ph.D in Management, Royal Holloway, University of London, London, 2012). 
Managing Corporate Waqf in Malaysia: Perspectives of Selected SEDCs and SIRCs

"This (development) is not under us (our responsibility)...you can ask this department..." 23

They may be able to raise their concerns in some platform such as officer level meetings. However, if it is not received favourably, the issue may slowly subside.

The above mentioned issue is also related to where the waqf unit/department is placed in the organizational structure. If it is a unit under a division, there is limit to how much the waqf unit can do. For example, in the SIRCK, waqf has only been entrusted to a dedicated unit in 2012. Previously, it straddled between the Baitul Mal Unit and Project Unit - only as a job specification. At that time, no one specific unit owned waqf matters, hence less attention was given to registration and related responsibilities. Currently, the waqf unit is hierarchically under the Development Division. ${ }^{24}$ This indicates that the waqf unit may not have full authority in making decisions affecting waqf matters. This may also be seen from staff responsibility in the unit.

The waqf unit in the SIRCK has one executive officer in charge of inspecting waqf land once an application has been made. In terms of line of reporting, the staff member is directly under the waqf officer. Depending on the authority requiring the service, the waqf officer may not have full authority to instruct the executive officer to prioritise waqf-related responsibilities, as the executive officer can also be instructed by other relevant units or divisions to undertake their tasks. In addition, the nomenclature used (i.e., "unit") gives an impression of the (un)importance of the unit of operation (i.e., waqf unit). Being located at this level indicates that the line of reporting can be hierarchically bureaucratic as compared to a division.

The last factor relates to the will of the higher authority. Although there may be opposition from other departments or units, the aspiration and authority of the Chairman/President/YDP of SIRC may overcome these difficulties. In case of the SIRCP, the Deputy YDP of SIRC is directly involved in ensuring the waqf agenda is prioritised. The waqf officer noted that:

"I am lucky here because our boss shares our (waqf department) aspiration..." 25

23 WO, SIRCK.

24 The information is obtained from interview. However the website does not show "Development Division".

25 WO2, SIRCP. 
In this case, even though, waqf is just a unit or a department under a bigger division, the will of the authority (i.e. the Deputy YDP as the CEO) can ensure that any waqf-related responsibility is fulfilled.

\section{c) Human and Financial Resources}

All three SIRCs interviewed share the same concern regarding staff strength, (i.e., lack of manpower). This seems to be a recurring theme in the SIRC generally ${ }^{26}$ and waqf specifically. ${ }^{27}$

The administrative responsibilities entail tasks such as attending to applicants, the post-application task such as verifying the existence of assets (in the case of land), and monitoring of waqf asset. This is not an exhaustive list of waqf-related responsibilities, but is highlighted to indicate that the responsibilities are wide-ranging and require assistance from other departments within the SIRCK. Therefore, there is a tendency that the process may be hampered as the waqf unit depends on other people in completing its tasks. This includes the need to verify waqf properties post-application. One informant said that:

"Our unit shares this staff (Surveying Officer - SO) with other departments. Although he is placed in this department, he is also required to do task by other units" ${ }^{28}$.

She confided that the service of this particular SO is also required by any unit or division within the SIRC. Therefore, apart from attending to waqfrelated responsibilities, the $\mathrm{SO}$ is also tasked to undertake land matters, but not related to waqf. Hence, there are several occasions where the person's service is required concurrently.

26 Abdul-Rahman, A. R. \& Goddard, A., 'Financial Management and Accounting in State Islamic Religious Councils in Malaysia: A Grounded Theory,' in New Horizons in Asian Management: Emerging Issues and Critical Perspectives, ed. D. R. Sharpe \& H. Hasegawa (Basingstoke, England: Palgrave Macmillan, 2007); Al-Habshi, S. O., 'Waqf Management in Malaysia,' in Islam and the Economic Development of Southeast Asia: The Islamic Voluntary Sector in Southeast Asia, ed. M. Ariff (Singapore: Institute of Southeast Asian Studies, 1991).

27 Osman, A.-Z., 'Accountability in Managing Waqf Properties: The Case of Two State Religious Councils in Malaysia'; Siraj, S. A. 'An Empirical Investigation into the Accounting, Accountability and Effectiveness of Waqf Management in the State Islamic Religious Councils (SIRCs) in Malaysia,' (Ph.D, Cardiff University, Cardiff, 2012).

28 WO, SIRCK. 
Managing Corporate Waqf in Malaysia: Perspectives of Selected SEDCs and SIRCs

In addition to staff sharing issues, the waqf unit itself receives applications (i.e., donating assets such as property and cash) "almost every week" (WO, SIRCK). Therefore, the volume of waqf-related tasks is huge. According to the waqf officer, there are approximately 2,000 'cases' needing attention. These include new applications, existing waqf that need monitoring, attending to waqf beneficiaries, and others. This strength of eight staff - whom do not devote all of their time to the waqf unit - cannot handle the responsibility efficiently. Both the sharing of staff and the volume of transactions underscore the need for additional staff for the waqf unit.

Similar cases are experienced in the SIRCP. The ability of the waqf department to address waqf-related problems sometimes depends on other parties. The waqf officer highlighted that some other officers from other departments may not fully understand his aspirations towards developing waqf. Therefore, during the officer's level meeting, his proposals may sometimes receive unfavourable responses from other officers (WO, SIRCP). He alluded that:

\section{"If we can do all this by ourselves, the process is quicker" 29}

This indicates the WO's "frustration" when dealing with certain tasks. He wishes for a full-time staff to be allocated to the waqf department in undertaking this responsibility. Despite their admission on the inadequate staff handling waqf-related responsibilities, those interviewed acknowledged that there has been some improvement in managing waqf assets. In th SIRCK, a dedicated waqf unit has already been established separating the Project Management unit and the Baitul Mal unit. Prior to this, waqf matters were ambiguously handled by Project Management and Baitul Mal, while in the SIRCP two officer level staff had been recruited focusing solely on waqf matters.

With regard to the SIRC in Negeri Sembilan, its subsidiary, PWNS is aware of the need for corporate waqf entities to manage and increase the value of waqf assets and properties. The real challenge in financing the development of waqf assets is insufficient funding. It is suggested that a collaborative effort with other institutions is one of the possible ways to finance such development.

\section{d) Relationship with Beneficiaries}

Since the establishment of PWNS, it has initiated several activities to raise funds from Muslims within Negeri Sembilan and the public at large. These activities include requesting donations through its cash waqf scheme and

29 WO, SIRCP. 
wealth waqf program. It also offers a range of products and services which include providing affordable clinics, dialysis centres, and giving opportunities for the small businesses to manage waqf marts and bazaars at selected mosque areas.

The collection from cash waqf scheme is used to support the operational costs of clinics and dialysis centres. Every ringgit they receive is utilised to further their mission of caring and curing people through quality health care. It also coordinates and manages the operations of clinics and dialysis centres to ensure that the objective of providing affordable health care and dialysis service to the poor is realized. These services are made possible with the professional support of Hospital Pakar Seremban (KPJ) and the financial support of MAINS. Since starting its operation in October 2003 until December 2012, the clinic and dialysis centre have extended its services to more than 25,113 patients from various ethnic groups and religious background with only a nominal charge of RM5 per treatment. ${ }^{30}$ In addition, the cash waqf is also used to buy or redeem Muslim lands in Negeri Sembilan which had been previous mortgaged.

Besides operating clinics and dialysis centres, PWNS is also involved in providing a platform for small-scale entrepreneurs to start businesses or expand their businesses within the vicinity of six selected mosques in Negeri Sembilan. This initiative is aimed at empowering them to have a stable income and to gain experience as entrepreneurs. Proceeds are disbursed according to a $40: 30: 30$ ratio whereby $40 \%$ is given to the respective mosques, $30 \%$ is reinvested in PWNS, and the last $30 \%$ is utilized as a sinking fund. ${ }^{31}$

Meanwhile, for the SIRC of Kelantan, the relationship with beneficiaries depends on the type of waqf. For specific waqf, this is normally not an issue because the SIRC has close contact with them. The waqf officer of the SIRCK noted that:

\section{"We allocate the money to them every year as this is what is stated in the waqf deed...we meet some of them also..." 32}

This shows that for specific waqf, the engagement is relatively direct. The officer illustrated a case where she often received queries from beneficiaries regarding why and when the money is going to be given to them.

\footnotetext{
30 Perbadanan Waqaf Negeri Sembilan, Klinik \& Pusat Dialysis Brosur (Negeri Sembilan: PWNS, 2015).

31 Perbadanan Waqaf Negeri Sembilan, Bazaar Wakaf and Wakaf Mart Brosur (Negeri Sembilan: PWNS, 2015).

32 WO, SIRCK.
} 
Managing Corporate Waqf in Malaysia: Perspectives of Selected SEDCs and SIRCs

For general waqf, however there is no specific measure to engage beneficiaries on a formal basis. Although all the assistance and aid is given to beneficiaries such as mosques, burial grounds, and schools, proactive steps such as requiring beneficiaries input are not in place. The interviewees argued that there is no particular reason to ask for any input from beneficiaries, as what is happening now is considered adequate:

"Normally, no...". When pressed further for the reason they responded: "...[it] never occurred to us [to do so]..." 33

A similar response was also received from the SIRCK waqf officer. While there may be some monitoring and controlling mechanism in the form of audits and from the Deputy YDP (WO, SIRCK) - such as monitoring spending and project management (WO1, SIRCP) - there is certainly a lack of effort towards engaging beneficiaries (for general waqf) in order to understand their needs.

In the SIRCP, there is also no direct engagement with beneficiaries of general waqf. However, since the waqf officer who is in charge of the initial process of registration is also involved in the development of waqf properties, the waqf department's influence appears to be greater compared to the situation in the SIRCK. In other words, although the waqf officer does not explicitly ask what beneficiaries need, their initial engagement with the public is for fulfilling the needs of beneficiaries. The waqf officer said that:

"...we did not do special meetings, but we ask people in the area what they would like to do with this property" 34

In this instance, although the final say rests on the SIRCP (upon recommendation from waqf officer), they do engage beneficiaries - albeit informally.

\section{DISCUSSION}

\section{Staff Strength: The Need for Quantity and Quality}

While the concern on insufficient staff prevails, the qualification of staff in charge of waqf differs between the states. In the SIRCK, the head of the waqf unit comes from a legal/Shariah background while in the SIRCP, the two highranking officers in the waqf department are economics/business graduates; one of them having been a bank officer for 20 years. Therefore, their approaches

$\begin{array}{ll}33 & \text { WO1, SIRCP. } \\ 34 & \text { WO2, SIRCP. }\end{array}$ 
may differ. It seems that in the SIRCK, the focus is more on dealing with the new waqf and addressing administrative matters regarding land registration. This is understandable as the unit is newly established and the process of marketing waqf and sorting out responsibilities are high on their agenda before embarking on waqf development. Meanwhile, the waqf officers in the SIRCP have moved towards developing waqf properties. The ex-banker waqf officer is also responsible for the investment matters of the SIRC. Therefore, with his experience and responsibilities, he seems to be able to leverage his wider authority to develop waqf.

\section{Facilitating Role by State Government}

Both SIRCs do not seem to receive the level of assistance required from their respective state governments. Instead of facilitating, there are instances where these state authorities are seen as hindrances. Despite the possibility of a government to government relationship ( $G$ to $G$ ), waqf officers have felt frustrated with the current relationship. Many reasons could be contributing to this. Abdul-Rahman noted that in the case of the SIRCK, the state government felt reluctant to interfere on these matters due to power relations; the state government does not want to be seen as too involved in areas where the palace has a big say. This context and the past relationship between the executive body and the palace makes the former more wary when dealing with the latter.

In the SIRCP, there were cases when the waqf officer felt that the effort to develop waqf property was more difficult compared to if it was a private company. While one of the waqf officers does not have any evidence to support his statement, he quipped that:

"I think they (state agency), see us as a competitor because we would like to develop and provide facilities and services to [the] public..." 35

Based on his information, the SIRCP is actively finding opportunities in adding value to its assets. In some cases, some assets, including waqf, are turned into income-generating assets. These assets include hospitals, palm tree plantations, shop lots, and other commercial ventures. It is based on these commercial activities that the waqf officer came to the above conclusion. He felt that the lack of a facilitating role by state department may be due to waqf being perceived as a commercial enterprise. However, he reasoned that:

35 WO2, SIRCP. 
Managing Corporate Waqf in Malaysia: Perspectives of Selected SEDCs and SIRCs

"The proceeds of all these ventures go back to the SIRCP. For waqf properties, we channel it back to the intended beneficiaries and the public such as renovating mosques, assisting schools, fencing cemeteries, and other relevant funding applications... " 36

In short, despite the existence of income-generating waqf assets - akin to commercial ventures - the proceeds are used to support waqf beneficiaries all over the state.

\section{The Authority and the Assistance}

There is a need for a wider authority or at least greater assistance extended to the waqf unit/department. The case of Perbadanan Wakaf Selangor (PWS) exemplifies a relatively easier decision making process since waqf is put as an entity by itself. In this instance, every department and/or division was created to work towards ensuring that waqf can benefit the beneficiaries.

However, if the authority to establish a separate entity is problematic, the SIRC may decide on giver wider authority within the existing structure by empowering waqf officers to be part of a bigger division. Alternatively, there needs to be a mechanism where waqf matters receive greater attention or priority in the organizational setup. This can be undertaken through setting up a dedicated committee at the higher level to facilitate waqf operations.

\section{Engaging $W a q f$ Beneficiaries}

The engagement process with waqf beneficiaries appears to happen only for specific waqf. As for general waqf, there is no evidence showing that active engagement is undertaken. White argues for the need to engage beneficiaries at a higher level (i.e., involving beneficiaries at the decision-making level). ${ }^{37}$ While this suggestion may not easily materialize due to the level of knowledge of the beneficiaries and their reluctance to get involved in the process, a greater

36 WO1, SIRCP.

37 White, S. C., 'Depoliticising Development: The Uses and Abuses of Participation (La depolitisation du developpement: usages et abus de la participation / Despolitisando o desenvolvimento: participacao: usos e abusos / Despolitizando el desarrollo: los usos y abusos de la participacion), Development in Practice, 6/1 (1996): 6-15. 
effort must be initiated to engage beneficiaries. Although we may not see beneficiaries as the "drivers" in the waqf effort, they should not also be seen as mere "passengers" in this process. This process should be undertaken in earnest (i.e., such engagement should be scheduled as required).

\section{CONCLUSION}

This study discusses the level of awareness and willingness of selected SEDCs and SIRCs in adopting different approaches in waqf initiatives. In short, the SEDCs of Perak, Perlis, and Kedah accepted the idea of corporate waqf entities managing and enhancing the value of waqf assets and properties, but this must be done within the current legal framework to avoid redundancy or going against the authority of HRH State Rulers. The SEDCs could consider the use of a matrix structure or hybrid organizational mechanism to run the corporate waqf entities with autonomy and by the code of governance.

The study found that there is lack of coordination between SEDCs and SIRCs with regard to waqf matters. The waqf divisions in selected SIRCs lack authority to make important decisions such as developing waqf assets or properties. Waqf officers are assigned with simple tasks such as the registration of waqf assets, whereas the authority to develop these assets are out of their hands.

The responsibility to manage waqf properties may rest on the SIRC. However, state government can play at least a facilitative role in ensuring that the processes are far more efficient and that the benefits reach all beneficiaries. This study provides cursory evidence on the extent to which the involvement of state agencies/department are very scant. There is an impression that, in certain cases, the state government is seen as a hindrance towards efficient waqf management. While this may be an isolated incident (or merely a sole waqf officer's impression), the state government should extend a helping hand in strengthening the waqf agenda. A more active state government role may even provide funding and direct involvement in waqf-related management. A successful waqf initiative may relieve state governments from providing selected services. In the end, this actually helps to reduce the state government burden. 
Managing Corporate Waqf in Malaysia: Perspectives of Selected SEDCs and SIRCs

\section{REFERENCES}

Abdul-Rahman, A. R. \& Goddard, A., 'Financial Management and Accounting in State Islamic Religious Councils in Malaysia: A Grounded Theory,' in New Horizons in Asian Management: Emerging Issues and Critical Perspectives, ed. D. R. Sharpe \& H. Hasegawa (Basingstoke, England: Palgrave Macmillan, 2007).

Ahmad Zaki Hammad, The Gracious Quran (Lisle, IL, USA: Lucent Interpretations, LLC, 2009).

Al-Habshi, S. O., 'Waqf Management in Malaysia,' in Islam and the Economic Development of Southeast Asia: The Islamic Voluntary Sector in Southeast Asia, ed. M. Ariff (Singapore: Institute of Southeast Asian Studies, 1991).

Aun. W. M., An Introduction to the Malaysian Legal System (Kuala Lumpur: Heinemann Educational Book, Asia Limited, 1975).

Chowdury, M. S. R. et al., 'Economics of Cash Waqf Management in Malaysia: A Proposed Cash Waqf Model for Practitioners and Future Researchers,' African Journal of Business Management, 5 (2011): 30.

Hanefah, H. M. M., Jali, A., Ramli, A. M., Sabri, H., Nawal, N. \& Shahwan, S., 'Waqf Models in Iskandar Malaysia: An Analysis,' https://comaif. files.wordpress.com/2013/09/2010-usim-waqf-models-in-iskandarmalaysia-full-paper.pdf., accessed on 20 October 2015.

Investment and Finance 'Coporate Waqf,' www.Islamic-finance/c/corporatewaqf.html., accessed on 19 October 2015.

JAWHAR, http://www.jawhar.gov.my/images/Keratan_Akhbar/bh050213\%20 r.pdf., accessed on 22 July 2015.

Kahf, M., 'The Role of Waqf in Improving the Ummah Welfare,' (Paper presented in the International Seminar on Waqf as a Private Legal Body, 6-7 January 2004, Medan).

Megat Abdul Rahman, M. M. G. \& Othman, A., 'Development of Waqf Land: Issues, Prospect, and Strategies,' Malaysian Journal of Real Estate, 2 (2006): 39-46.

Muslim Ibn al-Hajjāj Abū al-Ḥasan al-Qushayrī al-Naysābūrī, Șaḥịh Muslim, Sahih, Book 13, The Book of Bequests (Kitāb al-Wașiyyah), Hadīth no. 4006, https://d1.islamhouse.com/data/en/ih_books/single/en_Sahih_ Muslim.pdf

Osman, A.-Z., 'Accountability in Managing Waqf Properties: The Case of Two State Religious Councils in Malaysia,' (Ph.D in Management, Royal Holloway, University of London, London, 2012). 
Perbadanan Waqaf Negeri Sembilan, Bazaar Wakaf and Wakaf Mart Brosur (Negeri Sembilan: PWNS, 2015).

Perbadanan Waqaf Negeri Sembilan, Brosur Profil (Negeri Sembilan: PWNS, 2015).

Perbadanan Waqaf Negeri Sembilan, Klinik \& Pusat Dialysis Brosur (Negeri Sembilan: PWNS, 2015).

Sayyid Sābiq, Fiqh al-Sunnah (Miṣr: al-Fatḥ li al-I'lām al-'Arab̄̄, 1425/2014).

Siraj, S. A. 'An Empirical Investigation into the Accounting, Accountability and Effectiveness of Waqf Management in the State Islamic Religious Councils (SIRCs) in Malaysia,' (Ph.D, Cardiff University, Cardiff, 2012).

Waqaf An-Nur Corporation (Johor: Johor Corporation Corporate Waqaf Concept, 2008).

White, S. C., 'Depoliticising Development: The Uses and Abuses of Participation (La depolitisation du developpement: usages et abus de la participation / Despolitisando o desenvolvimento: participacao: usos e abusos / Despolitizando el desarrollo: los usos y abusos de la participacion),' Development in Practice, 6/1 (1996): 6-15. 